\title{
O Partido dos Panteras Negras
}

\author{
Wanderson da Silva Chaves*
}

Bloom, Joshua; Martin, Jr., Waldo E. Blacks Against Empire: The History and Politics of the Black Panther Party. Berkeley e Los Angeles: University of California Press, 2013. 540p.

Poucos aspectos da história norte-americana do pós-guerra são tão opacos quanto a história do Partido dos Panteras Negras. Sua vertiginosa trajetória de ascensão e queda, entre 1967 e 1971 — e encerramento definitivo das atividades, em 1982, de forma praticamente anônima - vem sendo disputada e fixada por duas narrativas principais, publicamente ainda em disputa, mas que, entretanto, discursivamente tendem a se encontrar. A sustentada pelo Federal Bureau of Investigation (FBI), mais conhecida por ser a adotada na cobertura jornalística nos EUA desde então, associa ao Partido um programa racista, fascista, sectário e separatista, que justificaria, em razão de ameaças à segurança nacional, a campanha de época pela destruição dos Panteras. A outra narrativa, calcada na fortuna crítica dos chamados "estudos afro-americanos", e sustentada principalmente pela militância e organizaçóes do nacionalismo negro, vincula o Partido a um projeto de busca da unidade e do orgulho racial, característicos da negritude. O mérito de Blacks Against Empire reside justamente na desconstrução destes dois lugares-comuns. Reconstrói-se, ao longo do livro, a lógica de atuação do Partido a partir de suas principais tensóes e ambiguidades: embora decisivas para o programa partidário, essas particularidades eram categoricamente ignoradas no trabalho de memória, e na historiografia.

O trabalho de Joshua Bloom, sociólogo da UCLA, e Waldo E. Martin Jr., historiador da Universidade da Califórnia em Berkeley, e autor experiente - com publicaçôes sobre escravidão, racismo, direitos civis e movimentos sociais — foi árduo. $\mathrm{O}$ livro começou a ser escrito em 2000, e no seu curso, mobilizou cerca de 50 pesquisadores e colaboradores diretos, reunindo mais de 12 mil páginas de documentos raros e inéditos, hoje, integrados aos acervos da Biblioteca de Estudos Étnicos e à Bancroft Library, de Berkeley. Quatorze teses acadêmicas foram desenvolvidas sob a cobertura desse projeto, que estendeu sua pesquisa a arquivos nacionais e internacionais, privados e governamentais, e retomou, por meio de entrevistas, e um sério esforço de certificação documental, a massa de testemunhos, ra Fria (USP). São Paulo, SP, Brasil. E-mail: wanderson_schaves@yahoo.com.br 
memórias e autobiografias que ainda são a principal fonte bibliográfica sobre o Partido e para boa parte das organizaçóes civis dos EUA dos anos 1960 e 1970.

O resultado desse empreendimento: uma boa narrativa factual, comparada ao desastre historiográfico das duas tendências da literatura temática, e que coloca imediatamente questóes inquietantes; particularmente, a de que os Panteras Negras, não apenas retoricamente, mas em agenda e estratégias, buscaram ser radical e efetivamente antirracistas.

Comparado às organizaçôes do Movimento dos Direitos Civis dos anos 1960, o Partido parece ter ido fundo e longe: tornaram-se uma organizaçáo nacional com forte presença nos grandes centros urbanos, e agindo, principalmente, fora do Deep South e da sua rede de organizaçóes religiosas, estudantis e profissionais negras. $\mathrm{O}$ projeto de Martin Luther King Jr., para os anos 1960, de que sindicatos, igrejas e o mainstream liberal colaborassem nas reformas econômicas, sociais e políticas destinadas à definitiva dessegregaçáo - a integração de todos à projetada beloved community - obteve pouco suporte fora das suas bases tradicionais, a classe média negra, e simpatizantes progressistas do Norte. Os colaboradores que não responderam à conclamação de King, todavia, não fizeram falta ao arco de alianças construído pelos Panteras. Profundo conhecedor da organização, o FBI sabia que seu projeto de desmantelamento do Partido passava principalmente por açôes de dissuasão aplicadas aos aliados: os órgãos da chamada Nova Esquerda, particularmente os envolvidos na luta contra a Guerra do Vietná; os "negros moderados", rescaldo do Movimento dos Direitos Civis; governos de Estados comunistas ou não alinhados; e lideranças, associaçóes e igrejas baseadas nas periferias das cidades, não apenas nos bairros negros. A estratégia: diplomaticamente, romper o suporte internacional; e com medidas policiais secretas, minar as pontes entre os diversos segmentos de classe da comunidade negra, bem como as conexôes "inter-raciais", que eram o grande patrimônio político do Partido.

Os Panteras Negras não eram secessionistas, nem partidários da negritude como projeto, embora a reivindicaçâo à herança de Malcolm X - que era uma meta partidária importante, particularmente o chamado à luta por "todos os meios necessários" contra o Estado e a polícia - tenha sido central para a sua atuação. Com relação a programas, nada de decisivo opôs o Partido à proposta de integração, que caracterizava a agenda pública de King. Curiosamente, ela seguia no sentido do seu aprofundamento, ao destacar mudanças estruturais para destruir - e não apenas reformar - dinâmicas raciais, como condiçáo para tornar os direitos civis realmente efetivos. A diferença em relação a King, sempre afirmada com muita ênfase, era tática: contra a resistência não violenta, advogava-se a autodefesa armada, e, ainda que nunca de forma consensual e programática, também o enfrentamento armado ao Estado como parte da sua atribuída vocaçáo de partido revolucionário. O FBI explorou publicamente essa escolha tática como uma aberta declaraçáo de guerra. E com uma massiva campanha de infiltração, sabotagem e extermínio, na qual 
buscou vincular o Partido a falsas açóes, defrontou os Panteras Negras intermitentemente aos dilemas estratégicos e éticos da instrumentalização política da violência.

A resposta dos autores à historiografia — que concede grande relevância às leituras policiais, ao heroísmo dos testemunhos, e aos atuais Movimentos Negros, que se pretendem herdeiros políticos do Partido - foi estritamente documental. Nela, há um esforço em distinguir as açôes secretas de Estado das realizadas pelos Panteras, e em separar a agenda e atuação do Partido daquela das organizaçóes raciais negras, posto que essa diferença tornou-se mais que retórica - tornou-se programática. E compreende-se bem ao longo do livro o porquê.

Fundado em 1966, o Partido dos Panteras Negras era, inicialmente, uma milícia armada, formada integralmente por homens, que atuava na região de Oakland, Califórnia. Suas principais atividades eram o monitoramento da polícia, via obstrução e denúncia da violência dos órgáos de segurança, e a intimidação - física e através de boicotes e mobilizaçôes públicas - de denunciados de racismo e infraçáo aos direitos civis. Os marcos dessa atuação eram inusitadamente legais. Segundo leis estaduais da época, o porte e o transporte de armas carregadas, em locais públicos ou veículos, eram permitidos se o armamento estivesse devidamente exposto, e fora de posição de tiro. Acompanhar açóes policiais também era permitido, desde que mantida distância. Huey Newton e Bobby Seale, estudantes de direito, e membros fundadores do Partido, fizeram essa descoberta legal, e nela apoia- ram a aplicação da autodefesa armada para além da situação - a invasão de residências sem mandado judicial - que primeiro havia mobilizado seus esforços.

Até 1967, o Partido era mais uma unidade, dentre várias outras, espalhadas pelos EUA, surgidas simultaneamente nessa época, que se autointitulavam Panteras Negras. Todas elas atendiam a um chamamento comum. Usando o animal símbolo do Lowndes County Freedom Organization (LCFO), organização política que o Students Non-Violent Coordinating Committee (SNCC) pretendia transformar em partido no Alabama, os Panteras de Oakland eram mais um grupo que buscava dar forma política ao slogan "Black Power", de Stokely Carmichael, líder do SNCC. Entáo, pouco conhecido fora do norte da Califórnia, o grupo de Newton, Seale e do jornalista de Ramparts, Eldridge Cleaver, por volta de outubro de 1968, já havia rapidamente unificado em torno da sua liderança todos os grupos de Panteras, aproximado e emparedado vários setores da esquerda norte-americana, estabelecido uma publicação oficial com tiragem de massa, reunido um orçamento anual milionário, angariado suporte internacional, e dominado o debate pela definiçáo dos sentidos do Poder Negro. Essa ascensão, que se alicerçou na atração dos jovens mobilizados nos confrontos raciais na era dos assassinatos de Malcolm X (1965) e King (1968), foi alcançada com dramáticas e bem-sucedidas açôes públicas, e após duras disputas interorganizacionais e partidárias.

Em razão de suas opçôes táticas, Newton, Seale e Eldridge Cleaver consideravam o Par- 
tido o único capaz de exercer algum esforço de politização sobre a massa de jovens negros que escolheu a violência. E graças ao perfil da sua liderança, os únicos que poderiam atrair identificação imediata. De fato, um histórico de pobreza, bom treinamento militar prévio, passagens por prisóes, eventuais aproximaçôes ao Nation of Islam (NOI) e um sério esforço de formaçáo intelectual os assemelhava a parte considerável da militância que ingressou nas cerca de 80 sucursais que os Panteras chegaram a ter no país. Inicialmente, o Partido espelhou a retórica racialista e nacionalista que emergiu nos confrontos e protestos, mas das suas proclamaçóes, na qual se declarava vanguarda partidária do "exército de libertação negro", dificilmente se poderia obter uma agenda nacionalista. Discursivamente difusa, e muito dependente da eficácia performativa das açóes e da sua poderosa iconografia, suas metas nem sempre óbvias eram a liberação do racismo, o combate à polícia, a autogestâo comunitária e a união tática dos negros como estágio preliminar e preparatório da luta "anticolonial" contra o Estado norte-americano a ser lançada.

Os Panteras eram a mais literalmente "fanonista" dentre as organizaçóes de base negra dos EUA, vinculação que foi pouco destacada pelos próprios autores. Isto significava uma aposta no programa de luta armada exposto em Os condenados da terra (1961), em que se apelava à violência como força liberadora pessoal e militar do domínio colonial. Esse potencial de transgressão, pensado para se dirigir contra o "exército doméstico de ocupação" que seria a polícia, era dirigido também contra o que era conside- rado, pelo Partido, o grande "maniqueísmo colonial" a ser revertido - a raça. Embora a liderança dos Panteras Negras tivesse bom domínio da literatura marxista e dos textos políticos de Che, Mao e Lênin que fizeram carreira naquela época, era Fanon a principal ferramenta do Partido no rechaço às organizaçôes cujo programa fosse "antibranco" ou que pretendessem disciplinar sua atuaçáo. Por uma ou por ambas as razóes, o SNCC, o Congress for Racial Equality (CORE), o braço político do NOI, o Revolutionary Action Movement (RAM) e o Partido Comunista dos Estados Unidos foram asperamente repelidos.

Após o estabelecimento de restriçóes legais ao uso de armas, em 1969, os Panteras se orientam para a montagem, nas suas sucursais, de clínicas médicas, refeitórios, cursos de formação política e escolas primárias, entre outras iniciativas cujo fim declarado era estabelecer a gratuidade, socialização, criação e a autogestão de serviços públicos dentro das comunidades negras. Sustentada por grande suporte e participaçáo voluntária, a iniciativa afetou o War on Poverty, grande programa federal de reforma urbana, terceirizado para empresas, fundaçôes, igrejas e organizaçóes negras. Publicamente, a política social de governo era ferida, na comparação, por sua atribuída timidez, inoperância e racismo. A essa reorientação, na qual o Partido transferiu para sua liderança "civil" a condução da maioria das açóes, coincidiu curiosamente uma brutal ofensiva policial, na qual se prendeu ou executou os principais quadros dos Panteras Negras, sucessivamente, cidade a cidade. 
Esse momento também coincidia com a construção de uma sólida aliança do Partido com os movimentos contra a Guerra do Vietná, da qual os dois segmentos se consideraram beneficiados. Orientando-se parcialmente pelas mudanças no discurso público dos Panteras, os grupos predominantemente estudantis, envolvidos nos protestos, foram acrescentando uma retórica anti-imperialista, e depois, crescentemente antifascista e anticapitalista, a seu próprio discurso antiguerra, inicialmente ligado ao pacifismo dos objetores de consciência. Essa conexão temática veio acompanhada de grande produtividade organizacional. Com apoio do Partido, são criadas, em comunidades de população hispânica, asiática, indígena e de "brancos pobres", organizaçôes similares às dos Panteras. Apoiados principalmente nestes novos grupos, e com suporte de aliados que incluíam igrejas, ativistas gays e feministas e grupos antirracistas, os Panteras Negras criaram o Comitê Nacional de Combate ao Fascismo, sem restriçôes de filiação. A emergência do que se designou, por esse comitê, de "Coalizão Arco-Íris", funcionou como uma correia de transmissão circular: cada grupo assumia sua pauta particular no esforço conjunto de oposição à Guerra no Vietnã, no coletivo de lutas liberatórias globais e domésticas, e na resistência à ofensiva policial.

O FBI mudou sua estratégia de combate aos Panteras em 1971. Naquele momento, embora não contasse com boa parte de seus quadros políticos, já presos, mortos ou exilados, o Partido atingiu seu auge de expansão, filiação e influência. Em um dos pontos al- tos do livro, Bloom e Martin Jr. descrevem como o Federal Bureau of Investigation, respondendo à guinada do governo Nixon, desarticulou a rede de apoiadores dos Panteras Negras e iniciou o seu declínio. Do isolamento que se produziu, seguiu-se a exposição de diferenças políticas e temáticas, contradiçóes retóricas e tensôes internas e com aliados que rapidamente tornaram o Partido politicamente insignificante.

Diplomaticamente, o compromisso de Nixon com a gradual retirada das tropas do Vietnã, o restabelecimento de relaçôes com China e Argélia e a conclusão da maioria das lutas de libertação nacional na África desmobilizou as organizaçóes estudantis antiguerra e inibiu o apoio internacional aos Panteras. Dava-se fim à pauta "anti-imperial" comum. Com a universalização das cotas raciais como política de Estado, bem como a ampla reforma universitária, que tornou os chamados "estudos afro-americanos" item curricular obrigatório, normalmente com dotação orçamentária e suporte departamental próprios, o governo Republicano capturou a atenção e conquistou a confiança da maioria dos aliados dos Panteras nas universidades e entre as classes médias. Alianças e acomodaçóes políticas são estabelecidas com estes setores: após terem sido expelidos ou hostilizados pelo Partido, a velha guarda do Movimento dos Direitos Civis e as jovens organizaçóes negras assumem, já dentro do governo, a implantaçáo dessas medidas que se tornariam, mais que a retomada das políticas sociais de Lyndon B. Johnson, o início da gestaçáo do multiculturalismo como proposta de ordem.

O faccionalismo também destruiu os 
Panteras. A liderança do Partido, quando desafiada a iniciar a prometida luta armada pela facção - depois conhecida por Black Liberation Army, optou por tentar preservar aliados politicamente moderados, especialmente entre seus principais patrocinadores. Huey Newton, que entáo se deslocava para o centro da máquina democrata na Califórnia, e para a gestão de programas de assistência comunitária em nada diferentes daqueles que já vinham sendo realizados nas várias instâncias de governo, desmilitarizou a imagem da organização, abandonou a retórica revolucionária, promoveu expurgos e estabeleceu uma rígida estrutura burocrática de mando. Além disso, estreitou laços com pequenas máfias do submundo de Oakland, dinâmica de despolitização que acabou por afastar, sobretudo, aos aliados e rede de contatos entre a Nova Esquerda. Feministas e gays externos às comunidades negras já haviam retirado seu apoio antes disso, em razão do persistente sexismo que supostamente se definia como traço da atuação dos Panteras.

Desbaratados por sucessivos raids policiais, mais duradouros que sua real relevância, as cisóes civis ou armadas do Partido perderam rapidamente, após 1973, a consistência programática que caracterizara sua existência anterior, como pretendida organização de massa. Assim, embevecidos e guiados apenas pelo heroísmo, os membros remanescentes, reduzidos ao terrorismo ou ao gangsterismo, deixaram de existir formalmente como grupo.

Embora tantas referências icônicas dos Panteras, desde a saudação de punhos erguidos à sua particular articulação dos impera- tivos do Black is beautiful - mais orgulhosa exposição de signos corporais que pesquisa de africanismos - povoem a moda, a cultura $p o p$ e o panteão de referências de inúmeros grupos políticos, ninguém seria capaz de reivindicar o espólio deles. Falando principalmente dos Estados Unidos, os autores argumentam que se deve recusar ver qualquer continuidade exatamente onde ela é mais mencionada e reivindicada: entre os advogados da chamada thug life, presentes nas expressóes dominantes do rap contemporâneo; e entre os ativistas das políticas raciais de Estado. Os argumentos de Bloom e Martin Jr. me convencem de que estes já seriam outra história, pois suas agendas e métodos eram não apenas diferentes: por defenderem, do centro do espectro político, sobretudo propostas de reforma e reordenamento da ordem racial, suas posiçóes seriam adversárias à posição antirracista, às lutas antiestatais e às táticas de recrutamento e politização do lúmpen criminal que os Panteras praticaram.

Com cuidadoso uso de documentação e crítica aos testemunhos, Blacks Against Empire ajuda a esclarecer o complexo trabalho de memória - que também é esquecimento e encobrimento - que atualmente sustenta (pode-se dizer, também no Brasil) a gestação de políticas ditas antirracistas. Embora não seja evidente, a definição do perfil da ordem democrática como ligado, não à Questão Política (liberdades), mas à resolução da Questão Social (compensação, reparação), envolve, de variadas formas, a história de malogro e sucesso de pessoas como os Panteras. 